\title{
Finnsheep and their utilization - experiences in temperate conditions
}

\author{
R.L. BAKER \\ Ruakura Agricultural Centre, Ministry of Agriculture \& Fisheries, \\ Hamilton, New Zealand
}

\begin{abstract}
The highly prolific Finnsheep (F) has been exported to more than 40 countries around the world to improve the reproductive performance of local breeds through crossbreeding. The infusion of one-half $\mathrm{F}$ into local breeds results in a substantial improvement in all reproductive traits with net reproduction (lambs weaned/ewe mated) being increased by about $25 \%$ in the British Isles and Western Europe and by up to 70-100 \% in New Zealand, South Africa and the USA. Heterosis for litter size at birth has been low or negligible in a number of crossbreeding studies involving $\mathrm{F}$.

Serious reservations have been expressed about the growth, fleece producton and carcass characteristics of F. While F-cross lambs are usually lighter at birth than local breeds, their weaning and post-weaning weights are often very similar, at least partly due to heterosis. Despite the perceived poor live conformation of purebred $\mathrm{F}$, the carcass weight, quality and composition of F-crosses have been very similar to local breeds or crosses. A striking feature of F-cross carcasses is that they have more kidney and less subcutaneous fat than local breeds. This may be a desirable feature of F-cross in extensive, pastoral farming situations to help sheep survive during droughts or periods of low pasture production. The fleece weight of the purebred $\mathrm{F}$ is $30-40 \%$ lower than most local breeds, particularly long-wooled breeds. However, the 1/4-F crosses have consistently been only 5-10 \% lower in fleece weight. Studies have reported comparable, or superior, processing qualities of F-cross wool.

F-cross ewes have generally been shown to have superior longevity, overall productivity and economic efficiency than local breeds across a diverse range of environments and farming systems. Some of the problems of integrating a highly prolific genotype into extensive, lowcost, sheep production systems are discussed. $\mathrm{F}$ has been utilized in many countries by producing a new synthetic population containing a certain proportion $(1 / 8$ to $1 / 2)$ of $\mathrm{F}$ ancestry. This approach is usually superior to other crossbreeding options such as stratified crossing or rotational crossing systems.
\end{abstract}

Index words: Finnsheep crossbreeding, reproduction performance, fleece, carcass, growth rate, economic productivity, longevity, heterosis 


\section{Introduction}

The Finnish Landrace or Finnsheep (F) is renowned for its prolificacy and produces an average litter size (LS) at birth of 2.6 lambs in Finland (27). Because within-breed selection to improve LS and overall reproductive performance in sheep is slow ( $1-2 \%$ per year), many countries have imported highly prolific breeds of sheep such as F and Romanov to improve the reproductive performance of local breeds by crossbreeding. MaiJala (38) reported that over 40 different countries have imported F since the Animal Breeding Research Organisation in Scotland first did so in 1962.

A number of comprehensive reviews of the performance of $\mathrm{F}$ and $\mathrm{F}$-crosses in many different countries have already been written (e.g. 1, 2, 6, 16, 26, 28, 38, 40, 43, 44, 66). This review will concentrate on experiences with F-crosses in temperate climates, drawing on publications from North America, Western Europe, South Africa (S.A.) and New Zealand (N.Z.) Particular emphasis will be placed on the overall productivity of F-crosses including not just reproduction, but growth and carcass production, wool production, lifetime production and longevity and overall biological and economic efficiency. Of particular interest to the author of this review are the problems associated with integrating a highly prolific genotype into extensive, lowcost, sheep production systems such as those in N.Z.

\section{Reproduction}

The reproductive performance of first-cross (F1) F ewes relative to the local breeds in the USA, the British Isles and Western Europe was summarised by MAIJALA (38) and is shown in Table 1. Similar information from N.Z. and South African trials are also included in Table 1. The relative reproductive performance of F1 Finn-cross ewes does vary around the world, due presumably to different environmental and management condi- tions and the productive level of the breeds against which they were being compared.

Despite this variation there is clear evidence in Table 1 that infusion of one half $\mathrm{F}$ into the local breeds results in a substantial improvement in all reproductive traits with net reproductive performance (i.e. lambs weaned/ ewes mated) being increased by about $25 \%$ in the British Isles and Western Europe and by up to $70-100 \%$ in N.Z., S.A. and the USA. In general, the reproductive level of many of the local breeds in Western Europe, (including some of the trials in Britain), are higher than the indigenous breeds in USA, N.Z. and S.A. Net reproductive averages close to $100 \%$ for the sheep populations in N.Z. and the USA and is $80-90 \%$ for the Merino population in S.A.

At least part of the superior reproductive performance of F1-ewes documented in Table 1 could be due to heterosis $(\mathrm{H})$. In a FMerino reciprocal crossbreeding study little or no $\mathrm{H}$ was found for LS at birth (35). The conclusion that the high LS of $\mathrm{F}$ is transmitted additively to its crossbred progeny is supported by a number of studies (e.g. 6, 38, 66). This conclusion does not necessarily hold for other reproductive traits and significant $\mathrm{H}$ has been reported for post-natal lamb survival in F-crosses (e.g. 66). Positive heterosis estimates for LS have been reported in F-Galway crosses (26) and F-Ile de France crosses (65). The potential pitfalls in estimating $\mathrm{H}$ for threshold, categorical traits are discussed by Land et al. (35). Similarly, Hanrahan (26) highlighted the experimental complications in making breed comparisons for ovulation rate (OR) or LS when body weight-fecundity relationships vary across breeds and crosses, as they did in F, Galways and Fingalways (FGalway crosses). Both Hanrahan (26) and VISSCHER (65) obtained different $\mathrm{H}$ estimates depending on whether estimates were based on a F1 minus midparent comparison or $2 \times$ (F1-F2) comparison. This has implications for breed utilization which will be discussed later. 
Table 1. Average relative reproductive and maternal performance of F1 Finn-cross ewes in different geographic areas compared with local breeds (100).

\begin{tabular}{lccccr}
\hline Trait' & USA $^{2}$ & $\begin{array}{c}\text { British }^{2} \\
\text { Isles }\end{array}$ & $\begin{array}{c}\text { Western }^{2} \\
\text { Europe }\end{array}$ & $\begin{array}{c}\text { New }^{3} \\
\text { Zealand }\end{array}$ & $\begin{array}{r}\text { South }^{4} \\
\text { Africa }\end{array}$ \\
\hline Fertility (EL/EM) & 151 & 107 & 109 & 115 & 109 \\
Litter size born (LB/EL) & 136 & 129 & 122 & 166 & 160 \\
Litter size weaned (LW/EL) & 150 & 122 & 122 & 151 & 183 \\
Lamb survival (LW/LB) & 105 & 100 & 110 & 95 & 114 \\
Net reproduction (LW/EM) & 209 & 125 & 124 & 174 & 197 \\
Weaning weight & 102 & 97 & 95 & 105 & 104 \\
\hline
\end{tabular}

' $\mathrm{EM}=$ ewe mated; $\mathrm{EL}=$ ewes lambing; $\mathrm{LB}=$ lambs born; $\mathrm{LW}=$ lambs weaned

2 From summary by MAIJALA (38)

${ }^{3}$ Meyer et al. (43) and Meyer (42). Relative to purebred Romneys.

4 From Hofmerr (28). Relative to purebred Merinos.

Young et al. (66) used path coefficient methodology to estimate standard partial genetic and phenotypic regression coefficients for number and weight of lambs weaned per ewe joined on fertility, LS, perinatal survival, postnatal survival and mean weaning weight. Under management conditions where neither fertility or lamb survival were optimal, the importance of both fertility and postnatal survival in determining number and weight of lambs weaned per ewe joined was clearly identified. Their results also demonstrated that the different reproductive traits may have quite different weightings in an optimum selection index, depending on the management and environmental conditions. These relationships are important when assessing the optimal way to utilize $\mathrm{F}$.

\section{Early sexual maturity}

A notable, and well-documented, feature of the F and F-crosses is its early sexual maturity. Both ewe and ram lambs are routinely used for breeding at $6-8$ months of age in Finland and fertile matings of ewe lambs have occurred at less than 4 months (40).

The reproductive performance of $\mathrm{F}$ and $\mathrm{F}$ cross ewe lambs is summarised in Table 2 from six of the larger, more definitive studies that have been reported. In all these studies F-crosses were clearly superior in fertility, LS and net reproduction to all the different breeds or crosses against which they were compared. In some crosses and in some environments, the high LS of the F-crosses resulted in lower lamb survival than the standard indigenous breeds.

Much of the variation among breeds or crosses in reproductive efficiency in ewe lambs can be attributed to the known large breed variation in both age and weight at first oestrus (20). In most studies, the F or F-cross have shown the earliest age at first oestrus and lower weights at puberty (e.g. 16, 35, 41, 52). Some exceptions have been reported including slightly lower age at first oestrus in Dorset crosses than F-crosses (10) and a 3-week earlier age at conception in ewe lambs in Romanov crosses than F crosses (64).

Male Fertility In addition to the early maturity of F rams, they have shown higher libido and mating capacity than the Scottish Blackface (34), Merino (35) and Suffolk (56). The motility, density and proportion of live sperm in the semen of $\mathrm{F}$ rams did not differ significantly from those of the Scottish Blackface (34).

\section{Growth and carcass traits}

While there is no doubt about the prolific characteristics of $\mathrm{F}$, considerable discussion has been evoked about the growth, conformation and carcass attributes of the breed. Com- 
Table 2. Reproductive performance of Finn-cross ewe lambs.

\begin{tabular}{|c|c|c|c|c|c|}
\hline $\begin{array}{l}\text { Locality of } \\
\text { study }\end{array}$ & Cross & $\begin{array}{l}\text { Fertility } \\
\text { (EL/EM) }\end{array}$ & $\begin{array}{c}\text { Litter } \\
\text { size } \\
(\mathrm{LB} / \mathrm{EL})\end{array}$ & $\begin{array}{c}\text { Lamb } \\
\text { survival } \\
(\mathrm{LW} / \mathrm{LB})\end{array}$ & $\begin{array}{c}\text { Net } \\
\text { reprod- } \\
\text { uction } \\
(\mathrm{LW} / \mathrm{EM})\end{array}$ \\
\hline $\begin{array}{l}\text { Minnesota' } \\
\text { USA }\end{array}$ & $\begin{array}{l}\text { Finn }(\mathrm{F}) \\
3 / 4 \mathrm{~F} \\
1 / 2 \mathrm{~F} \\
1 / 4 \mathrm{~F} \\
\text { Standard }\end{array}$ & $\begin{array}{l}0.95 \\
0.92 \\
0.92 \\
0.79 \\
0.72\end{array}$ & $\begin{array}{l}1.66 \\
1.56 \\
1.38 \\
1.20 \\
1.08\end{array}$ & $\begin{array}{l}0.88 \\
0.74 \\
0.47 \\
0.69 \\
0.64\end{array}$ & $\begin{array}{l}1.39 \\
1.06 \\
0.60 \\
0.65 \\
0.50\end{array}$ \\
\hline $\begin{array}{l}\text { Clay Center }{ }^{2} \\
\text { USA }\end{array}$ & $\begin{array}{l}1 / 2 \mathrm{~F} \\
\text { Standard }\end{array}$ & $\begin{array}{l}0.85 \\
0.58\end{array}$ & $\begin{array}{l}1.56 \\
1.08\end{array}$ & $\begin{array}{l}0.47 \\
0.53\end{array}$ & $\begin{array}{l}0.62 \\
0.33\end{array}$ \\
\hline $\begin{array}{l}\text { Dubois }{ }^{3} \\
\text { USA }\end{array}$ & $\begin{array}{l}1 / 2 \mathrm{~F} \\
1 / 4 \mathrm{~F} \\
\text { Standard }\end{array}$ & $\begin{array}{l}0.91 \\
0.76 \\
0.24\end{array}$ & $\begin{array}{l}1.53 \\
1.22 \\
1.06\end{array}$ & $\begin{array}{l}0.67 \\
0.64 \\
0.63\end{array}$ & $\begin{array}{l}0.93 \\
0.59 \\
0.16\end{array}$ \\
\hline $\begin{array}{l}\text { Oregon } 4 \\
\text { USA }\end{array}$ & $\begin{array}{l}1 / 2 \mathrm{~F} \\
\text { Standard }\end{array}$ & $\begin{array}{l}0.72 \\
0.41\end{array}$ & $\begin{array}{l}1.62 \\
1.22\end{array}$ & $\begin{array}{l}0.65 \\
0.74\end{array}$ & $\begin{array}{l}0.77 \\
0.37\end{array}$ \\
\hline Ireland ${ }^{5}$ & $\begin{array}{l}\mathrm{F} \\
1 / 4 \mathrm{~F} \\
\text { Galway }\end{array}$ & $\begin{array}{l}0.77 \\
0.47 \\
0.39\end{array}$ & $\begin{array}{l}1.21 \\
1.10 \\
1.12\end{array}$ & & \\
\hline Great Britain ${ }^{6}$ & $\begin{array}{l}1 / 2 \mathrm{~F} \\
\text { Standard }\end{array}$ & $\begin{array}{l}0.78 \\
0.61\end{array}$ & $\begin{array}{l}1.47 \\
1.17\end{array}$ & $\begin{array}{l}0.77 \\
0.78\end{array}$ & $\begin{array}{l}0.88 \\
0.56\end{array}$ \\
\hline
\end{tabular}

' Oltenacu and Boylan (48). Standard = Suffolk, Targhee, Minnesota 100.

2 Dickerson (16). Standard = Suffolk, Hampshire, Dorset, Rambouillet, Targhee, Corriedale.

${ }^{3}$ Ercanbrack and Knight (21). Standard = Rambouillet, Targhee, Columbia.

4 Cedillo et al. (10). Standard = all crossbreds from Suffolk and Columbia ewes mated to North Country Cheviot, Dorset and Romney rams.

5 QUIRKE (53).

${ }^{6}$ BARKER (2). Standard = mostly crossbreds. Sire breeds are Border Leicester, Teeswater, Suffolk, Scottish halfbred, Clun and Dorset Horn over many dam breeds.

pared with the conformation of many of the domestic breeds against which it has been evaluated, $\mathrm{F}$ has usually been rated very poorly. BARKer (3) described $\mathrm{F}$ as a fine-boned, rather long-legged sheep with a somewhat angular conformation and poor in musculature, especially over the hindquarters. Traditionally, the breed in Finland had a fairly low mature weight. However, Maijala (39) showed that over the period from 1948-1987, breeders in Finland have markedly increased both growth and fleece weight, without prejudicing the reproductive performance. While this increase may be partly environmental due to better management and nutrition, it is likely that some of this improvement is genetic in origin.

Most of the reports from around the world evaluating $\mathrm{F}$ for growth and carcass traits were based on importations made in the early (Ireland and Scotland) to late (USA and Canada) 1960s. It may be important to distinguish these early importations from more recent importations - e.g. the importation of the F into N.Z. in 1984 (62).

Despite the perceived poor growth and conformation of $\mathrm{F}$, there is now ample evidence that the breed is not as deficient in this area as originally thought. The comprehensive review by Maijala (38) showed that while average lamb birth weight and ewe liveweight of both $1 / 2$ and $1 / 4 \mathrm{~F}$ crosses were some $10-20 \%$ lower than domestic breeds, average lamb weaning weights and post-weaning daily gains were very similar to the domestic breeds. The weaning weights and post-weaning gains of $1 / 2 \mathrm{~F}$ crosses slightly exceeded the domestic breeds, most likely due to heterosis. 
For all traits summarised by MaIJALA (38), purebred $\mathrm{F}$ had lower growth than domestic breeds against which they were compared.

The carcass traits which were summarised by MaiJala (38) were carcass weight, dressing $\%$, percentages of fat, lean and bone in the carcass, eye muscle area, backfat thickness, percentage kidney and pelvic fat, hindsaddle weight, quality and leg conformation. Despite the perceived poor live conformation of purebred $\mathrm{F}$, the carcass weight, quality and composition of F-crosses have been very acceptable and very similar to other domestic breeds or crosses. The most interesting feature of $\mathrm{F}$ purebred or crossbred carcasses has been the relatively high percentage of fat in the total carcass due to more kidney (internal) fat and similar or less subcutaneous fat than local breeds.

In seasonal, pasture grazing, sheep production systems such as in N.Z., Australia and S.A., fat reserves in the sheep can be very important to help sheep to survive during droughts or periods of low winter pasture production. A sheep breed which preferentially stores fat internally rather than externally could be highly desirable.

Two recent reports evaluated growth and carcass attributes of $\mathrm{F}$ crosses in intensive feeding systems in Canada. LiretTe et al. (36) reported the effect of breed (Suffolk, F and their reciprocal crosses) on the conformation, classification, tissue distribution, chemical composition and organoleptic characteristics of carcasses from 40 lambs (10 per breed or cross) slaughtered at 120 days of age. Although the number of lambs in this study are relatively small, the differences among breeds and crosses (Table 3 ) are, in general, very consistent with other published reports and Maijala's (38) review. This study is, however, one of the more detailed reports on carcass quality and carcass composition. The data from $\mathrm{F}$ crosses clearly demonstrate that there are no major detrimental effects of the $1 / 2-\mathrm{F}$ ancestry on carcass weights, carcass cutability, carcass composition, tissue distri- bution or eating qualities. However, both the purebred $\mathrm{F}$ and the $\mathrm{F}$ crosses had a lower carcass classification under the Canadian system than the purebred Suffolks and hence a lower commercial value. A similar result was reported by Boylan et al. (7) for F crosses in the American carcass classification system. However, carcass classification based on conformation did not reflect the carcass composition, cutability, tissue distribution or eating qualities in this study. This conclusion is supported by many other studies and applies both within breeds and across breeds (e.g. 32, 33). A strong case can be made for basing carcass classification systems which affect payments to producers on yield of red meat rather than subjective, visual conformation assessments.

FAHMY (22) reported a study where growth and carcass traits were evaluated for the DLS breed (Dorset-Leicester-Suffolk) and six of its crosses with $\mathrm{F}$ rams ranging from $1 / 8 \mathrm{~F}$ to $6 / 8 \mathrm{~F}$. Entire ram lambs were slaughtered at about $43 \mathrm{~kg}$ liveweight. The only carcass traits which showed a significant linear trend with each 1/8 increase in F proportion were \% kidney fat $(0.15 \pm .04)$ and subcutaneous fat thickness $(0.14 \pm .05)$. In all other aspects crosses with various proportions of $\mathrm{F}$ breeding produced lambs comparable in quality to those from the DLS.

Some interesting early results for growth and carcass characteristics are now coming available from the most recent importation (1984) of the F, Texel and Oxford Down breeds into N.Z. (12). Some of the carcass characteristics of pasture-fed crossbed (F1) ram lambs out of Romney and Coopworth ewes and sired by F, Texel, Oxford Down, Border Leicester and Suffolk rams are shown in Table 4. The lambs were serially slaughtered in two groups. The average slaughter age was 200 days and the average carcass weight $17 \mathrm{~kg}$. The results in Table 4 are consistent with other reports in showing, that relative to Suffolk crosses, F crosses are relatively leaner subcutaneously by 30 to $40 \%$, but have about $30 \%$ more kidney (internal) fat, slightly 
Table 3. Breed effects on carcass traits of ram lambs. (36)'

\begin{tabular}{lcrrr}
\hline Trait & $\begin{array}{c}\text { Suffolk } \\
(\mathrm{S})\end{array}$ & $\begin{array}{c}\text { Finn } \\
(\mathrm{F})\end{array}$ & SxF & FxS \\
\hline Slaughter wt (kg) & 33.1 & 26.1 & 33.2 & 32.9 \\
Average daily gain (g) & 262 & 204 & 260 & 255 \\
Carcass wt (kg) & 16.8 & 12.6 & 16.3 & 16.3 \\
Dressing \% & 50.1 & 47.7 & 48.8 & 48.9 \\
Classification ${ }^{2}$ & 2.9 & 1.3 & 2.5 & 2.2 \\
Muscle \% & 60.6 & 61.1 & 62.3 & 61.0 \\
Fat \% & 15.3 & 16.9 & 15.6 & 18.4 \\
Bone \% & 24.1 & 21.4 & 3.1 & 20.8 \\
Back fat (mm) & 6.0 & 3.3 & 14.4 & 3.6 \\
Kidney fat g/kg & 10.0 & 18.6 & 8.0 & 13.6 \\
Sensory evaluations & & & 8.1 & 6.5 \\
$\quad$ Flavour & 6.9 & 7.4 & 8.8 & 8.8 \\
Juiciness & 7.7 & 8.2 & & 9.6 \\
$\quad$ Tenderness & 7.9 & & & \\
\hline
\end{tabular}

' Results averaged for entire and castrated ram lambs

${ }^{2} \mathrm{~A}=3, \mathrm{~B}=2, \mathrm{C}=1$

${ }^{3}$ All values on a 15-point scale; Flavour: $1=$ lacking lamb flavour, $15=$ intense lamb flavour. Juiciness: $1=$ dry, 15 = juicy. Tenderness: 1 = very tough, $15=$ very tender.

Table 4. Carcass characteristics' of crossbred ram lambs by breed of sire and relative to Suffolk crosses (100) ${ }^{2}$.

\begin{tabular}{lrcrrr}
\hline Trait & Finn & Texel & $\begin{array}{c}\text { Oxford } \\
\text { Down }\end{array}$ & $\begin{array}{c}\text { Border } \\
\text { Leicester }\end{array}$ & Suffolk $^{3}$ \\
\hline Tissue depth - GR $(\mathrm{mm})$ & 76 & 73 & 93 & 109 & 7.3 \\
Fat depth - C $(\mathrm{mm})$ & 62 & 62 & 85 & 96 & 2.9 \\
Kidney fat $(\mathrm{g})$ & 131 & 75 & 97 & 100 & 20.6 \\
Eye muscle area - (cm) & 96 & 907 & 100 & 97 & 101 \\
Carcass length $(\mathrm{cm})$ & 103 & 99 & 99 & 102 & 98.4 \\
Leg length $(\mathrm{cm})$ & 104 & & & 44.0 \\
\hline
\end{tabular}

1 Adjusted for carcass weight

2 From Clarke et al. (12)

${ }^{3}$ Least squares means

longer, leggier carcasses, and smaller eye muscle areas. It is particularly interesting to note that $\mathrm{F}$ crosses were as lean subcutaneously as Texel crosses and that this leanness was even more pronounced at higher carcass weights as illustrated in Figure 1. Average growth differences among these crosses are best indicated by contemporaneous female lambs which were not slaughtered. Body weights (adjusted for birth date, dam breed and birth-rearing rank), at about 5 months of age, gave relative breed rankings of: Oxford crosses (106), Suffolk and F crosses (100), Texel crosses (96) and Border Leicester crosses (92).

\section{Wool production}

The value of wool produced is of relatively minor importance in Finland and some of the sheep production systems in which the $\mathrm{F}$ has been evaluated (e.g. Western Europe and some parts of North America). However, this is certainly not the case in N.Z., Australia and S.A., where $50 \%$ or more of the total income from a sheep enterprise can come from wool.

It is clear that the purebred $\mathrm{F}$ is not competitive with many other breeds of sheep in terms of either greasy (GFW) or clean fleece weight. The average GFW for $\mathrm{F}$ ewes in Fin- 


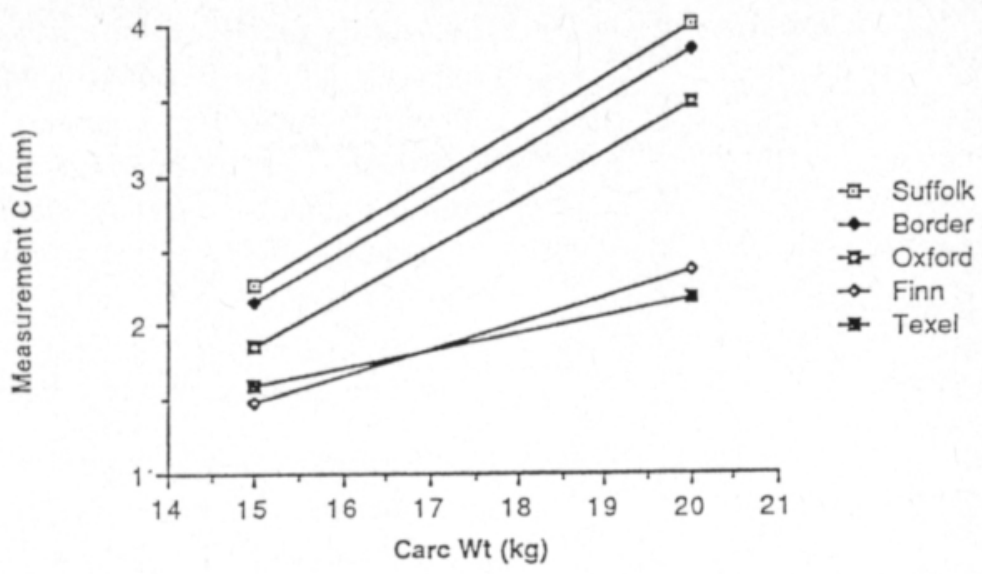

Fig. 1. Estimated fat depths (C, mm) at carcass weights of 15 and $20 \mathrm{~kg}$ (from Clarke et al., 1988).

land is about $2.8 \mathrm{~kg}(39)$ and on average this is $30-40 \%$ lower than other breeds against which it has been evaluated (38). In terms of wool quality traits the purebred $\mathrm{F}$ has a staple length longer or comparable to other longwooled breeds, with a fibre diameter (FD) of 25-28 microns and very few medullated fibres $(38,40)$. Donald and ReAD $(17)$ judged the wool as semilustrous with a notably soft and silky handle. This could make it very suitable for home-spinning enterprises.

GFW from $\mathrm{F}$ crosses in a variety of different production systems is summarised in Table 5 from a representative sample of studies in the USA and Ireland. Table 6 summarises similar information for studies in Canada, N.Z. and S.A., and also includes FD from two of the studies. It is interesting to note that $1 / 4$ F crosses have consistently been only $5-10 \%$ lower than many local breeds against which they have been compared. In some cases, when the local breeds have not been renowned for their wool production, both $1 / 4$ and $1 / 2$ $\mathrm{F}$ crosses have been similar to, or better than, the local breeds (i.e. Cochran et al., $1984-$ vs the Dorset; FAнmy, 1987 - vs the DLS breed).

The effect of $\mathrm{F}$ crossbreeding on FD depends very much on the FD of the local breeds. Crossing with the fine-wooled breeds such as the Merino in S.A. (28) or the Rambouillet, Targhee and Columbia at Dubois
(21) consistently results in reduced GFW and coarser wool and both these factors will affect wool returns. In contrast, crossing the $\mathrm{F}$ with breeds with coarser wool ( $30-40$ microns) will have relatively little or no effect on monetary returns because of slightly reduced FD. For example, Bigham and Meyer (4) reported that F-Romney first crosses had fleeces only 2 microns finer than the Romney.

\section{Processing characteristics}

DRUMmOND et al. $(18,19)$ sampled yearling and two-year old fleeces from the $\mathrm{F}$ crossbreeding experiment at the US Sheep Experiment Station, Dubois (i.e. Rambouillet, Targee and Columbia purebreds plus $1 / 2$ - and 1/4-F crosses), and assessed products processed on the worsted manufacturing system. These studies demonstrated that, although there were some differences in various fibre characteristics of wool from the purebreds vs F-crosses, there was no difference in the quality of the finished manufactured yarns and fabrics.

Very similar results were reported by HoFMEYR (28) who assessed the processing characteristics of wool from purebred Merinos and all the F1 crossbreds in this trial (i.e. out of Merino ewes and sired by F, Cheviot, Bleu de Maine, Border Leicester, Merino Landschafe and Texel). Wool from the Meri- 
Table 5. Wool production of Finn-cross ewes in the USA and Ireland.

\begin{tabular}{|c|c|c|c|}
\hline $\begin{array}{l}\text { Locality } \\
\text { of study }\end{array}$ & Cross & $\begin{array}{l}\text { Greasy } \\
\text { fleece wt } \\
(\mathrm{kg})\end{array}$ & $\begin{array}{l}\text { Relative } \\
\text { fleece wt }\end{array}$ \\
\hline $\begin{array}{l}\text { Minnesota' } \\
\text { USA }\end{array}$ & $\begin{array}{l}\text { Finn }(\mathrm{F}) \\
3 / 4 \mathrm{~F} \\
1 / 2 \mathrm{~F} \\
1 / 4 \mathrm{~F} \\
\text { Standard }\end{array}$ & $\begin{array}{l}2.1 \\
2.5 \\
2.9 \\
2.9 \\
3.3\end{array}$ & $\begin{array}{r}64 \\
76 \\
88 \\
88 \\
100\end{array}$ \\
\hline $\begin{array}{l}\text { Dubois' } \\
\text { USA }\end{array}$ & $\begin{array}{l}1 / 2 \mathrm{~F} \\
1 / 4 \mathrm{~F} \\
\text { Standard }\end{array}$ & $\begin{array}{l}3.7 \\
4.3 \\
4.8\end{array}$ & $\begin{array}{r}77 \\
90 \\
100\end{array}$ \\
\hline $\begin{array}{l}\text { Oregon' } \\
\text { USA }\end{array}$ & $\begin{array}{l}1 / 2 \mathrm{~F} \\
\text { Standard }\end{array}$ & $\begin{array}{l}1.9 \\
2.2\end{array}$ & $\begin{array}{r}86 \\
100\end{array}$ \\
\hline $\begin{array}{l}\text { Oregon }{ }^{2} \\
\text { USA }\end{array}$ & $\begin{array}{l}\text { Finn } \\
\text { Hampshire } \\
\text { Columbia and } \\
\text { Targhee }\end{array}$ & $\begin{array}{l}2.9 \\
3.7 \\
6.2\end{array}$ & $\begin{array}{r}47 \\
60 \\
100\end{array}$ \\
\hline $\begin{array}{l}\text { Clay Center }{ }^{3} \\
\text { USA }\end{array}$ & $\begin{array}{l}1 / 2 \mathrm{~F} \\
\text { Border } \\
\text { Leicester-cross }\end{array}$ & $\begin{array}{l}2.9 \\
3.1\end{array}$ & $\begin{array}{r}94 \\
100\end{array}$ \\
\hline $\begin{array}{l}\text { Virginia }{ }^{4} \\
\text { USA }\end{array}$ & $\begin{array}{l}1 / 2 \mathrm{~F} \\
1 / 4 \mathrm{~F} \\
\text { Dorset }\end{array}$ & $\begin{array}{l}2.7 \\
2.7 \\
2.5\end{array}$ & $\begin{array}{l}108 \\
108 \\
100\end{array}$ \\
\hline Ireland 5 & $\begin{array}{l}1 / 2 \mathrm{~F} \\
\text { Standard- } \\
\text { crosses } \\
\text { Galway }\end{array}$ & $\begin{array}{l}2.8 \\
3.0\end{array}$ & $\begin{array}{r}93 \\
100\end{array}$ \\
\hline Ireland ${ }^{6}$ & $\begin{array}{l}1 / 2 \mathrm{~F} \\
1 / 4 \mathrm{~F} \\
\text { Galway }\end{array}$ & $\begin{array}{l}2.8 \\
3.1 \\
3.2\end{array}$ & $\begin{array}{r}88 \\
97 \\
100\end{array}$ \\
\hline
\end{tabular}

1 Oltenacu and Boylan (49) and other references and standard breeds in Table 2 footnote. Minnesota average of 1- and 2-year fleeces; Dubois average lifetime production ( $1-7$ years); Oregon - yearling fleece.

2 Galuvan et al. (24). Average lifetime production.

${ }^{3}$ Magid et al. (37). Average of 2- and 3-year old ewes.

4 Cochran et al. (13). Average lifetime production.

5 More, O'Ferrall and Timon (44). Average 2-5 year production. Standard $=$ Border Leicester and Cheviot crosses.

${ }^{6}$ Hanrahan (25). Average of yearling and 2-year old fleeces.

no and the F-Merino had the best spinnability. The yearns spun from the different wool lots were then woven into cavalry twill fabric. The results, to quote the author, were:

"The finer wools (Merino and F-Merino) showed less faults and end breakages and the resulting fabrics were fuller and stronger, draping better with better crease recovery and less wrinkling. These wools had the highest relaxation and felting shrinkage. It is worthy of note that the F-Merino wool, with many physical qualities in common with Merino wool, showed less breakage while F-Merino fabric exhibited lower relaxation shrinkage and only half the felting shrinkage».

\section{Lifetime production and longevity}

Concern has been expressed that highly productive, and especially highly prolific sheep such as F, may have a shorter productive life than less prolific breeds. A few studies have evaluated the $\mathrm{F}$ and $\mathrm{F}$ crosses for longevity and two of the more definitive of these are summarised in Table 7.

In Minnesota, Boylan (6) reported an $11 \%$ lower longevity for purebred F (56 months) than Suffolk or Targhee ewes (63 months). However, all the F-crosses had greater survival than the parental breeds due to substantial levels of individual $\mathrm{H}(13.4 \%)$ and maternal $\mathrm{H}(12.8 \%)$, with $\mathrm{H}$ being greater in Suffolk crosses than Targhee crosses.

In the Oregon study, crossbred ewes from the North Country Cheviot, Dorset, F or Romney sires and Suffolk or Columbia dams were maintained on hill pasture or irrigated pasture management systems (30). On irrigated pasture, F-crosses had similar longevity to Romney and Dorset crosses, while on hill pastures the $\mathrm{F}$ crosses had the lowest longevity. For F, Romney and Cheviot crossbreds, longevity was greater under the management system in which productivity was greater (Table 7). These results demonstrated that at least part of the breed differences in cumulative lifetime lamb production was dependent upon breed differences in longevity, a trait that has received little emphasis in breed evaluation experiments. NoRman and HoHENBOKEN (47) discussed causes of death and culling and plotted attrition rates in this Oregon study. Illness $(42 \%)$ was the most comon cause of attrition, and there were no significant breed effects for internal parasite loads or foot soundness or footrot. 
Table 6. Wool production of F-cross ewes in Canada, N.Z. and South Africa.

\begin{tabular}{llcrc}
\hline $\begin{array}{l}\text { Locality } \\
\text { of study }\end{array}$ & Cross & $\begin{array}{c}\text { Greasy } \\
\text { Fleece wt } \\
(\mathrm{kg})\end{array}$ & $\begin{array}{c}\text { Relative } \\
\text { fleece wt }\end{array}$ & $\begin{array}{c}\text { Fibre } \\
\text { Diameter } \\
\text { (microns) }\end{array}$ \\
\hline Quebec' $_{\text {Canada }}$ & Finn (F) & 2.08 & 84 & 20.5 \\
& $3 / 4 \mathrm{~F}$ & 2.24 & 90 & 22.2 \\
& $1 / 2 \mathrm{~F}$ & 2.54 & 102 & 23.4 \\
Irene & $1 / 4 \mathrm{~F}$ & 2.48 & 99 & 23.7 \\
South Africa $^{2}$ & DLS & 2.49 & 100 & 25.5 \\
New Zealand $^{3}$ & $1 / 2 \mathrm{~F}$ & 4.6 & 84 & 24.7 \\
& Merino & 5.5 & 100 & 21.5 \\
\hline
\end{tabular}

' Fанму (23). DLS = 1/2 Dorset, 1/4 Leicester, 1/4 Suffolk. Average of first 3 shearings.

Hofmerr (28). Average ewe fleece weights.

${ }^{3}$ Sorrenson and Scott (59). Ewe wool production.

In the study at Dubois in the USA differences in attribution rate of ewes were accounted for by examining cumulative production in terms of cumulative weight of lamb weaned plus the cumulative wool production through seven years of age (21). For the total monetary value of lifetime production, taking the unit value of wool to be worth 2.5 times the unit value of lamb live weight, the $1 / 4$ and $1 / 2$ F-cross ewes surpassed the straightbreds (Rambouillet, Targhee and Columbia ewes) by $18 \%$ and $29 \%$, respectively.

Cochran et al. (13) reported that 1/2 FDorset and 1/4 F-Dorset and straightbred Dorset ewes did not differ in attrition rates for ewes exposed to up to 6 reproductive years.

\section{Economic productivity or efficiency}

HoHENBOKEn (29) discussed problems involved with economic analysis of breed evaluation in sheep and reviewed the relatively sparse array of experiments in which economic returns (gross revenue) or economic efficiency (net revenue) have been reported. Some of these studies have involved the F or F-cross ewes and are summarised in Table 8 for economic productivity (monetary value of production).
While economic productivity has been derived in different ways in different studies (Table 8 ), the $1 / 2 \mathrm{~F}$ ewe has consistently outproduced the local breeds or crosses by about $25 \%$ (range $20-40 \%$ ) and the $1 / 4 \mathrm{~F}$ ewe by about $14 \%$ (range $9-18 \%$ ). The exception was the F x Suffolk ewe in the Oregon study which showed a marked interaction with the two different management systems imposed, with the highest production of all crosses on

Table 7. Ewe longevity of Finn and Finn-crosses.

\begin{tabular}{llll}
\hline $\begin{array}{l}\text { Locality } \\
\text { of study }\end{array}$ & Cross & $\begin{array}{l}\text { Ewe } \\
\text { Longevity } \\
\text { (months) }\end{array}$ & \\
\hline Minnesota' & Finn (F) & 56 & \\
USA & 3/4 F & 64 & \\
& $1 / 2 \mathrm{~F}$ & 68 & \\
& 1/4 F & 77 & \\
& Suffolk & 63 & \\
& Targhee & 63 & Hill \\
& & Irrigated & \\
& & pasture & pasture \\
Oregon ${ }^{2}$ & 1/2 Finn & $58.9(169)$ & $52.8(134)$ \\
USA & 1/2 Romney & $58.3(132)$ & $55.2(111)$ \\
& 1/2 Dorset & $58.1(171)$ & $59.1(134)$ \\
& 1/2 Cheviot & $51.3(96)$ & $56.9(122)$ \\
\hline
\end{tabular}

1 Boylan (6)

2 Hohenboken and Clarke (30). In brackets cumulative weight $(\mathrm{kg})$ of lamb weaned per ewe entering the experiment, up to 5-years of age. All crosses were out of both Suffolk and Columbia dams. 
Table 8. Economic productivity for Finn-cross ewes.

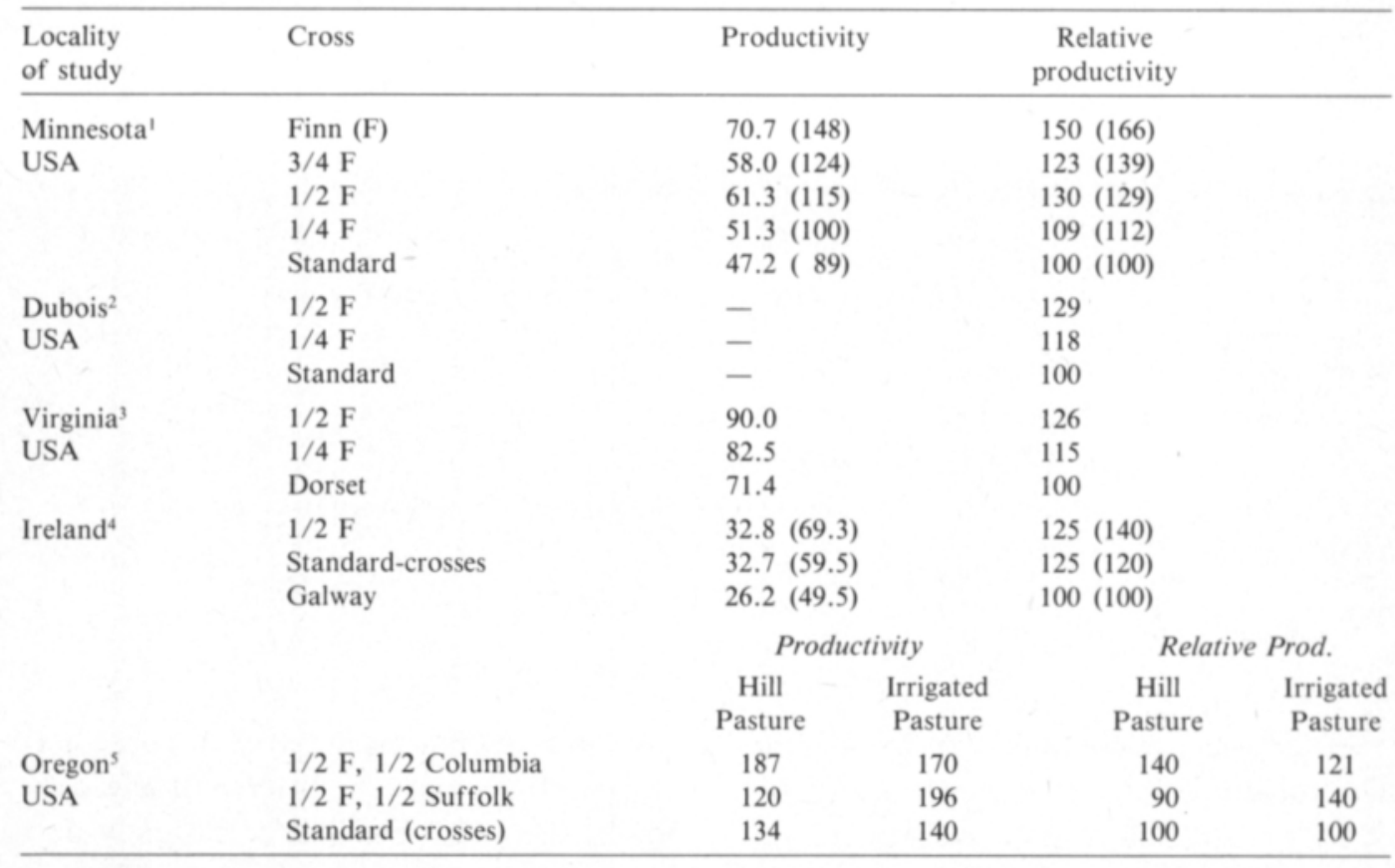

1 Oltenacu and Boylan (49). Productivity = Cumulative wt of lamb and fleece per ewe mated for ewes lambing at 1 and 2 years of age, based on the ratio of 1:3 for the values per kg of lamb and wool. In brackets, productivity/100 kg ewe body weight. Standard = average of Suffolk, Targhee and Minnesota 100 purebred ewes.

${ }^{2}$ Ercanbreck and Knight (21). Standard = average of Rambouillet, Targhee and Columbia ewes. Cumulative lifetime (7 yrs) productivity per ewe mated with a ratio of 1:2.5 for values per $\mathrm{kg}$ of lamb and wool.

${ }^{3}$ Cochran et al. (13). Productivity = Gross income per ewe lambing with a lamb to wool ratio of 1:1.4.

${ }^{4}$ More, O'Ferrall and Timon (44). Productivity = Weight of lamb weaned per ewe mated (per $100 \mathrm{~kg}$ ewe body weight). Standard $=$ Border Leicester and Cheviot crosses.

5 SAOUd and Hohenboken (55). Productivity = Lifetime gross income per ewe mated from lifetime lamb production (including orphans) and ewe salvage value. Wool income not included. Standard breeds are all crossbred ewes - see Table 7.

irrigated pastures and the lowest production on the hill pasture. The Irish study was actually a measure of biological productivity (lifetime weight of lamb weaned per ewe mated) since no monetary values were given. Both the Irish and the Minnesota study showed that expressing production relative to ewe body weight accentuated the productivity of the lighter F or F-cross ewes.

HoHENBOKEN (29) noted that reports in which costs as well as revenues have been considered are very rare for sheep breed evaluations. Five such studies involving F-crosses are summarised in Table 9. The N.Z. and the Irish study both estimated economic efficiency in terms of gross margins per ewe (gross rev- enue from lamb and wool minus variable costs). There was a $55 \%$ advantage over straightbred Romneys for the $1 / 2-\mathrm{F}$ in N.Z. and a $41 \%$ advantage of the $1 / 4-\mathrm{F}$ over the straightbred Galway in Ireland. In the N.Z. study it was estimated that allowing additional labour costs for the F-crosses at lambing time reduced the advantage over the Romney a little to $51 \%$ and the advantage over the Border Leicester cross (the most productive locally derived cross) from $18 \%$ to $15 \%$ (59).

The studies reported by CAMERON et al. (9) and OWEN (51) both involved synthetic breeds developed in Britain and both included about $50 \% \mathrm{~F}$ in their genetic composition. Economic efficiency was $11 \%$ and $28 \%$ greater than 
Table 9. Economic efficiency of Finn-cross ewes.

\begin{tabular}{|c|c|c|c|c|c|}
\hline $\begin{array}{l}\text { Locality } \\
\text { of study }\end{array}$ & Cross & $\begin{array}{l}\text { Economic } \\
\text { Efficiency }\end{array}$ & & $\begin{array}{l}\text { Relative } \\
\text { economic } \\
\text { efficiency }\end{array}$ & \\
\hline New Zealand' & $\begin{array}{l}\text { 1/2 Finn } \\
1 / 2 \text { Border Leicester } \\
\text { Romney }\end{array}$ & $\begin{array}{l}23.80 \\
20.20 \\
15.40\end{array}$ & & $\begin{array}{l}155 \\
131 \\
100\end{array}$ & \\
\hline Ireland ${ }^{2}$ & $\begin{array}{l}1 / 4 \text { Finn } \\
\text { Galway }\end{array}$ & $\begin{array}{c}+10.10 \\
-\end{array}$ & & $\begin{array}{l}141 \\
100\end{array}$ & \\
\hline $\begin{array}{l}\text { England and }{ }^{3} \\
\text { Wales }\end{array}$ & $\begin{array}{l}\text { 1/2 Finn (Dam line) } \\
\text { Border Leicester-cross }\end{array}$ & $\begin{array}{l}151 \\
136\end{array}$ & & $\begin{array}{l}111 \\
100\end{array}$ & \\
\hline \multirow[t]{3}{*}{ Wales $^{4}$} & $\begin{array}{l}\text { 1/2 Finn (Cambridge) } \\
\text { Border Leicester-cross }\end{array}$ & & & $\begin{array}{l}128 \\
100\end{array}$ & \\
\hline & & \multicolumn{2}{|c|}{ Economic eff. } & \multicolumn{2}{|c|}{ Relative eff. } \\
\hline & & $\begin{array}{c}\text { Hill } \\
\text { pasture }\end{array}$ & $\begin{array}{l}\text { Irrigated } \\
\text { pasture }\end{array}$ & $\begin{array}{c}\text { Hill } \\
\text { pasture }\end{array}$ & $\begin{array}{c}\text { Irrigated } \\
\text { pasture }\end{array}$ \\
\hline Oregon $^{5}$ & $1 / 2 \mathrm{~F}, 1 / 2$ Columbia & 44.6 & 31.1 & 1115 & 410 \\
\hline U.S.A. & $1 / 2 \mathrm{~F}, 1 / 2$ Suffolk & 3.6 & 54.6 & 900 & 730 \\
\hline & Standard (crosses) & 0.4 & 7.5 & 100 & 110 \\
\hline
\end{tabular}

I SORRENSON and SCOTt (59). Gross margins per ewe (dollars)

2 Hanrahan (26). Gross margins per ewe (pounds)

${ }^{3}$ CAmeron et al. (9). Gross lamb returns per ewe mated per unit of sheep weight (ewes and lambs) maintained (pounds)

4 OWEN (51). Ratio of lamb production/estimated feed intake

5 SAOUd and HoHenboken (55). Lifetime net revenue per ewe - gross revenue from lamb and ewe sales minus estimated feed and ewe purchase costs (dollars). Standard crosses defined in Table 7.

Border Leicester-cross ewes, respectively. Neither study included wool income in their gross returns.

In the Oregon study SAOUd and HoHeN. BOKEN (55) found that F-crosses consistently exceeded the local crossbred ewes in net revenue with the advantage being more marked on hill pasture than irrigated pasture. However, $\mathrm{F} \times$ Suffolk ewes generated much more net revenue on irrigated pasture than hill pasture, consistent with their gross returns on the two systems (Table 8 ). These crossbred ewes were all mated as ewe lambs on the irrigated pasture. Only the $\mathrm{F} \times$ Suffolk ewe lambs had a positive net return for the first year of production. Wool income was not credited to net revenue in this study. The authors stated that the breed rankings for either gross or net revenue were unlikely to be altered by consideration of wool income. In an earlier report on this study, Cedillo et al. (10) analysed the first year's gross income including wool income.
They found that $\mathrm{F} \times$ Suffolk ewes generated the highest income, whereas the Romney $\times$ Columbia ewes generated the least. The ranking for the eight crossbred groups was identical to that reported for the first year of production by SAOUd and HOHENBOKEN (55) ignoring wool income.

Analyses of the impact on the national economy of introducing new breeds have been carried out in N.Z. SORRENSON and SCOTT (59) carried out a cost-benefit analysis, necessarily based on a number of simplifying assumptions, to predict the national economic returns from $\mathrm{F}$-crosses allowing for the costs required to import, quarantine and evaluate the new breeds and crosses. The authors estimated that the internal rate of return to the nation of this expenditure could be about $25 \%$. This analysis was updated by BushNELL and HUTTON (8), based upon what they considered as conservative predictions of adoption of 1/2- and 1/4-F crosses, at a time 
when consideration was being given to re-import the $\mathrm{F}$ into N.Z. An internal rate of return on public investment of over $80 \%$ was predicted. BushNell and HutTon (8) also updated the gross margin analyses originally undertaken by SORRENSON and SCOTT $(59-$ see Table 9). They estimated that an increase in gross margin per ewe of $15 \%$ could be achieved on hill country farms by changing from straightbred Romneys to 1/4-F. On the more intensively farmed, easier country this advantage would increase to $28 \%$ for $1 / 2-\mathrm{F}$ over straightbred Romneys.

\section{Utilization of the Finn}

A comprehensive genetic model of genetic diversity among breeds includes additive genetic breed differences in individual maternal and paternal performance of purebreds; $\mathrm{H}$ for individual, maternal and paternal performance; and recombination effects in gametes produced by crossbred parents $(14,15)$. Recombination effects as defined by DiCKERSON (15) are the failure of $\mathrm{H}$ to be retained in proportion to heterozygosity.

The cumulative advantages of crossbreeding in sheep in terms of both additive breed effects and $\mathrm{H}$ have been clearly identified in reviews by NitTer (45) and CLARKE (11). Both authors identified the lack of critical experiments to evaluate the possible importance of recombination effects in sheep. From somewhat sparse information available at that time, Clarke (11) concluded that the firstcross $(\mathrm{F} 1)$ performance was a relatively poor predictor of subsequent performance in advanced generations ( $\mathrm{F} 2, \mathrm{~F} 3$, etc) of crossbreeding programmes. If $\mathrm{H}$ is primarily determined by dominance effects of genes then in advanced generations of crossbreeding programmes should be retained in proportion to retained heterozygosity. If a significant part of the $\mathrm{H}$ results from the epistatic effect of genes then the level of $\mathrm{H}$ retained in advanced generations of crossbreeding cannot be easily predicted from the $\mathrm{H}$ estimated in the first generation (i.e. performance of the F1 crosses relative to the average of the parental breeds).

Young et al (67) reviewed 12 sheep crossbreeding experiments where $\mathrm{H}$ retention or recombination effects had been estimated or could be derived from the published esperimental data. The authors concluded that $\mathrm{H}$ in advanced crossbred generations could not be accurately predicted from initial $\mathrm{H}$ and retained heterozygosity. In some experiments the amount of $\mathrm{H}$ retained was less than expected, but in a few cases significantly more $\mathrm{H}$ was retained than expected. Thus, loss of parental epistatic gene combinations does not necessarily imply negative effects on all traits as often understood from the commonly used term 'recombination loss'.

Of those 12 experiments two involved Fcrosses (Minnesota and Clay Center studies in the U.S.A.) and two involved Romanov crosses (France and Spain). In general, recombination effects were small and relatively unimportant in these studies, suggesting that the development of synthetic (composite) populations or new breeds is an effective way of utilizing $\mathrm{H}$ and additive breed effects. For many of the reproductive traits, in both $\mathrm{F}$ - and Romanov-crosses, the magnitude of the additive breed effects were much larger than quite low, and sometimes negative $\mathrm{H}$ estimates. There were, however, some exceptions to this generalization. For example, in the Minnesota study the F2 performances of FSuffolk and F-Targhee were usually inferior to the F1 by more than expected from retained heterozygosity, but this was not true for crosses involving the Minnesota 100 breed. This does not necessarily mean that all $\mathrm{H}$ is lost, but that the level of initial $\mathrm{H}$, and $\mathrm{H}$ retained in advanced generations, must be determined by experimentation involving specific breed combinations of interest.

Given these results on $\mathrm{H}$ retention, it is perhaps not surprising that a number of different synthetic breeds have been developed around the world which include the F. These 
include the Fingalway in Ireland $(25,26,57)$; the ABRO Dam line in Scotland (58); the Cambridge breed in Britain $(50,51)$ and the Polypay in the U.S.A. (61). At Clay Center two composite populations are being developed, one involving 1/2 F, 1/4 Suffolk, 1/4 Targhee for use in an annual lambing system and another line consisting of $1 / 2 \mathrm{~F}, 1 / 4$ Dorset, 1/4 Rambouillet for use in an accelerated lambing system (67). Two synthetic dam lines are also being developed at the Animal Research Centre in Ottawa (1). Both lines contain approximately $50 \% \mathrm{~F}$ in their breed composition and are being developed under an accelerated lambing programme (8-month schedule), with all lambs removed from their dams at birth and artificially reared.

In the Netherlands a synthetic dam line called the Flevolander is being developed based on $\mathrm{F}$ and Ile de France breeds (65). The development of a new synthetic breed was favoured over a three-breed cross (Texel sire $x$ F-Ile de France dam) because of the simplicity of the system at the farm level. VISSCHER (65) reported quite substantial levels of $\mathrm{H}$ for reproductive traits in this cross. Although the development is not complete, there is no apparent decline in reproductive performance in the synthetic ewes compared with F1 ewes.

A unique method of utilising the $\mathrm{F}$ was used in Norway (60). A crossbreeding experiment with the F in Norway established that the inclusion of $1 / 4 \mathrm{~F}$ in the Norwegian ewe population would lift LS by $0.20-0.25$ lambs without any major effect on other production traits. $\mathrm{H}$ for reproductive traits and growth rate were found to be negligible. Thus, $1 / 2 \mathrm{~F}$ rams were included in the comprehensive performance and progeny test programme in Norway from 1976. The marked effect of this infusion of $\mathrm{F}$ ancestry on national sheep production in Norway is documented by STEINE (60), not only in terms of advantages in LS and the overall production index, but also advantages in ease of lambing, lamb viability, lambing performance at 1-year of age and lower body weights of adult ewes.
While there are many examples of successful infusion of $\mathrm{F}$ genes into new breeds or composite populations it does not necessarily mean that this is the only way to utilize $\mathrm{F}$. NitTER (45) pointed out the advantages of a rotational crossbreeding system, particularly when $\mathrm{H}$ levels are high. Similarly, TerriLl (61) discussed the advantages of a continuous multi-breed non-systematic rotational crossing system versus either straightbred populations or a stratified crossbreeding system that must maintain a relatively high proportion of straightbreds.

An experimental evaluation of a rotational crossbreeding system involving Columbia or Targhee (Whiteface breeds), Hampshire and F was reported by Gallivan et al. (24). Using breed and $\mathrm{H}$ estimates derived from their study, the productivity of a number of different crossbreeding systems was evaluated; three-breed terminal crosses were the most productive (i.e. terminal sire mated to a crossbred ewe). However, the authors noted that the crossbred ewes would require a substantial proportion of straightbred ewes to maintain them, which would lower the overall productivity of the system. For farms producing their own replacements it was suggested that a three-breed rotation was likely to be most productive. However, this study did not include a synthetic interbred population, which could also be very productive. It was noted that $\mathrm{F}$ did little to enhance productivity in this study, because of negative effects on wool and lamb growth and because the management system imposed did not allow their higher prolificacy to be expressed as more lambs weaned (i.e. lambs in excess of two per litter were not raised by the ewe).

The study by Gallivan et al (24) highlights the fact that it may be critical in many production systems to optimize the proportion of $\mathrm{F}$ ancestry in a population, and this is not easily done with rotational crossbreeding. It is interesting to note the approach taken in Ireland (26). In order to minimize problems of acceptability, efforts are being taken to reduce the 
proportion of $\mathrm{F}$ ancestry required for a given level of prolificacy. One approach taken has been to apply intense selection for OR in a F line and then combine this extra-prolific $\mathrm{F}$ line with Galway genes from a line which has been selected for increased LS for 15 years. Work is continuing to produce and $1 / 8 \mathrm{~F}, 7 / 8 \mathrm{Gal}$ way sheep with a predicted gain of 0.3 to 0.4 in LS over the average Galway population presently farmed in Ireland.

Very similar logic was applied when N.Z. selected $\mathrm{F}$ sheep in Finland to import into N.Z. in 1984 (62). Two distinctly different lines of F were sampled. One line had an average LS (2.6 lambs) and selection emphasis was put on growth and size. The other sample was selected solely on high LS using the comprehensive performance records available in Finland. This sample of $\mathrm{F}$ ewes had an average LS of 3.5, about 2 standard deviations above the population mean. The aim is to utilize this line of $\mathrm{F}$ to produce $1 / 8 \mathrm{~F}$ crosses in N.Z., without prejudicing wool production, growth or carcass production to any marked degree.

\section{Husbandry considerations}

The economic studies summarised in Table 9 would suggest that the $\mathrm{F}$ can be successfully integrated into a range of different sheep farming systems and improve economic efficiency. These studies were by no means completely comprehensive, however, in accounting for all costs of production. Some concerns commonly expressed about highly prolific and productive genotypes are about lamb survival, particularly in litters of 3 or greater; lack of information on feed intake and feed costs of individual grazing sheep; and the need for production to be assessed on a per hectare basis, especially in pastoral farming systems.

NitTer (46) investigated the economic response to increasing genetic potential for reproductive performance. A simple method was derived to obtain the economic response per unit change of LS. Costs associated with increased LS included decreased lamb sur- vival, decreased birth weights of lambs and increased costs of feeding and labour of ewes with different LS, particularly during late pregnancy and during lactation. It was noted that all effects were difficult to quantify and varied with different breeds and management systems. NitTer stated that he would not consider the economic response to introducing a highly prolific breed such as the $\mathrm{F}$ or the Romanov into a population since this would certainly cause a deterioration in growth and carcass traits. Since the present review shows this is not necessarily true, it appears that NitTER's conclusions could still apply to introducing $\mathrm{F}$ as well as within-breed genetic improvement.

NitTer used as an example the economic response per unit change of LS in the Merinoland breed in southern Germany under four different production systems and for a wide range of average LS (1.1 to 2.5 ). In all four production systems, ranging from intensive to extensive, the economic value of extra lambs born was high as long as the average LS did not exceed 1.5. At higher LS the economic value dropped dramatically, particularly in the most extensive system where negative economic values were obtained above an average LS of 2.1. This study appears to be very relevant to many pastoral sheep systems where easy case systems and keeping costs low are critical to profitability. However, in N.Z., for example with an average national lambing percentage of about $100 \%$, there is still considerable scope to improve LS before these limiting factors start to take effect.

Some of the consequences of high flock prolificacy in an intensive grassland sheep production system in England were reported by Boaz and Tempest (5). The system involved high herbage production, high annual stocking rates and the artificial rearing and subsequent indoor fattening of a proportion of the lambs born. Three ewe breeds of different potential prolificacy were compared - i.e. Scottish Halfbred (Border Leicester male $\mathrm{x}$ Cheviot female), Welsh Speckleface and F- 
Scottish Blackface. The study also attempted to augment prolificacy by hormone treatment. This was not a success due to both poor conception rates and high lamb mortality in large LS. The authors concluded that promotion of natural high prolificacy through choice of breeds offered the best prospect of overall prolificacy. Over a five year period the lambs sold per 100 ewes mated without hormone treatment were 201 for the F-cross, 200 for the Scottish Blackface and 102 for the Welsh Speckleface. Problems identified in maintaining the highly productive genotypes included lower than planned lamb growth rates to slaughter, low lamb birth weights and reduced viability in large litters; inadequate milk yield of the ewes; maintaining high ewe liveweights at mating resulted in reduced appetite on silage in late pregnancy; and a significant negative phenotypic regression between a ewe's LS and her GFW.

RoBINSON (54) reviewed the nutritional requirements of the pregnant and lactating ewe and noted that while it is relatively easy to define the net requirements of nutrients for highly prolific ewes, transforming these into feeding strategies presents a considerable challenge. ROBINSON (54) confirmed the finding of BOAZ and TEMPEST (5) that it is often difficult to meet the high demands for energy in late pregnancy and early lactation in highly prolific ewes. However, RoBInson pointed out that mild energy deficits in late pregnancy and early lactation are still compatible with normal reproductive performance in prolific ewes, provided they are not accompanied by a specific protein deficiency.

TREACHER (63) reviewed the information on the milk yield and voluntary feed intake levels of ewes suckling three or more lambs and considered ways in which the growth of multiple-born lambs may be improved in pasture systems. He concluded that improvements in prolificacy must be linked to selection or crossbreeding programmes to improve the milk production potential of prolific breeds. The high milk yield in East Friesian- cross ewes in Britain was noted. STEINE (60) also noted that, with increased LS in Norway through introducing $F$ genes then milk production of the ewe became a critical factor for both lamb growth rate and lamb viability to weaning. Semen from East Friesian rams has recently been imported into Norway for this purpose (Steine, pers. comm.).

Given the problems with triplet and higherorder LS it is interesting to note that differences in the distribution of OR among prolific breeds have been reported. MEYER (42) reported that $1 / 2$-F-cross ewes had $15 \%$, $70 \%$ and $15 \%$ single, twin and triplet ovulations, respectively, while corresponding values for Booroola-cross ewes were $32 \%$, $37 \%$ and $31 \%$, at a similar mean OR. While little is known about the genetic nature of the distribution of OR or LS there would be considerable advantages in breeding a sheep with an average LS of two and relatively few triplet or higher-order litters.

HOHENBOKEn (29) suggested that there was a critical need for bioeconomic computer simulation models for sheep production to estimate more comprehensively the overall economic effects of different breeds or crosses and breeding systems and possible interactions with management systems. OWEN (51) pointed out that new techniques or new sheep breeds need to be evaluated not only in terms of overall economic efficiency but also in terms of ease of management. He illustrated, as have others, that optimal LS at birth and OR vary markedly according to husbandry conditions. He also presented information on forage requirements of a number of new sheep breeds and crosses in Britain including 1/4 F and the prolific Cambridge breed.

While there are many reports of successful infusion of $\mathrm{F}$ into sheep populations it is important before concluding this review to note at least one instance where this was not true. INIGUEZ et al. (31) reported an evaluation of the Rambouillet, Dorset and F and their F1 crosses in a spring mating/autumn lambing system under good nutrition in the central val- 
ley of California. The F had a late onset of the breeding season which limited the usefulness of even $1 / 2-\mathrm{F}$ ewes as an economically viable genotype in an autumn lambing system in California. Despite the result of this study there are other reports of the good performance of the $\mathrm{F}$ in accelerated lambing systems, usually under intensive management sys- tems (e.g. 38).

Overall, it appears that careful planning should ensure that a small percentage of $\mathrm{F}$ genes $(1 / 8$ to $1 / 2)$ can be fitted into most management systems (perhaps suitably modified) in temperate countries to give an increase in productivity and net income.

\section{References}

1. Ainsworth, L., Fiser, P.S., Heany, D.P., Lang FORD, G.A. \& SHRESTHA, J.N.B. 1985. Intensive husbandry of fecund sheep. In: Genetics of Reproduction in Sheep. Eds., R.B. Land and D.W. Robinson, Butterworths, London: 399-409.

2. Barker, J.D. 1975. A field trial of Finnish Landrace rams as sires of crossbred ewes. Anim. Prod. 20: 371-380.

3. Barker, J.D. 1977. Finnish Landrace sheep in Great Britain. In: Ann. Rept. Anim. Breed. Res. Org.: $17-22$.

4. Bigham, M.L. \& Meyer, H.H. 1979. Wool production of exotic x Romney sheep. Proc. N.Z. Soc. Anim. Prod. 38: 115-117.

5. BonZ, T.G. \& Tempest, W.M. 1975. Some consequences of high flock prolificacy in an intensive grassland sheep production system. Anim. Prod. 20: 219-232.

6. Boylan, W.J. 1985. Crossbreeding for fecundity. In: Genetics of Reproduction in Sheep. Eds., R.B. Land and D.W. Robinson. Butterworths, London.: 19-24.

7. Boylan, W.J., Berger, Y.M. \& Allen, C.E. 1976. Carcass merit of Finnsheep crossbred lambs. J. Anim. Sci. 42: 1413-1420.

8. Bushnell, J. \& Hutton, J.B. 1982. Better use of pasture with Finnish Landrace cross. The N.Z. Agr. Econ. 3(Nov 4): 7-8 and 47.

- 9. Cameron, N.D., Smith, C. \& Deeble, F.K. 1984. Performance of lambs from three crossbred ewe types. Anim. Prod. 39: 81-87.

10. Cedillo, R.M., Hohenboken, W.D. \& Drummond, J. 1977. Genetic and environmental effects on age at first estrus and on wool and lamb production of crossbred ewe lambs. J. Anim. Sci. 44: 948-957.

11. ClakKe, J.N. 1982. Utilisation of breed resources in the improvement of goat productivity. Proc. 2nd Wld. Cong. Genet. Appl. Livest. Prod. 5: 635-654.

12. Clarke, J.N., Parratt, A.C., Malthus, I.C., Amyes, N.C., Uluee, A.E. \& Woods, E.G. 1988. Carcass composition of exotic sheep breeds. Proc. N.Z. Soc. Anim. Prod. 48: (in press).

13. Cochran, K.P., Notter, D.R. \& McClaugherty, F.S. 1984. A comparison of Dorset and Finnish Landrace crossbred ewes. J. Anim. Sci. 59: 329-337.

14. Dickerson, G.E. 1969. Experimental approaches in utilizing breed resources. Anim. Breed. Abstr. 37: 191-202.

15. Dickerson, G.E. 1973. Inbreeding and heterosis in animals. In: Proceedings of Animal Breeding and Genetics Symposium in Honor of Dr J.L. Lush. Champaign, Illinois, U.S.A., ASAS and ADSA: 54-77.

16. Dickerson, G.E. 1977. Crossbreeding evaluation of Finnsheep and some U.S. breeds for market lamb production. North Centr. Reg. Publ. No. 246, $30 \mathrm{p}$.

17. Donald, H.P. \& Read, J.L. 1967. The performance of Finnish Landrace sheep in Britain. Anim. Prod. 9: $471-476$.

18. Drummond, J., O'Connell, R.A. \& Price, D.A. 1980. Processing characteristics of Finn-cross wool. J. Anim. Sci. 50: 405-410.

19. Drummond, J., O'Connell, R.A. \& Colman, K.L. 1982. The effects of age and Finnsheep breeding on wool properties and processing characteristics. J. Anim. Sci. 54: 8-11.

20. Dyrmundsson, O.R. 1973. Puberty and early reproductive performance in sheep. 1. Ewe lambs. Anim. Breed. Abstr. 41: 273-289.

21. Ercanbrack, S.K. \& Knight, A.D. 1985. Lifetime (seven years) production of 1/4 and 1/2 Finnish Landrace ewes from Rambouillet, Targhee and Columbia dams under range conditions. J. Anim. Sci. 61: 66-77.

22. FАнму, M.H. 1985. The accumulative effect of Finnsheep breeding in crossbreeding schemes: growth and carcass traits. Can. J. Anim. Sci. 65: 811-819.

23. Fанму, M.H. 1987. The accumulative effect of Finnsheep breeding in crossbreeding schemes: wool production and fleece characteristics. Can. J. Anim. Sci. 67: 1-11.

24. Gallivan, C., Hohenboken, W.D. \& Vavra, M. 1987. Breed and heterosis effects on wool and lamb 
production of rotationally crossed ewes. J. Anim. Sci. 64: 43-49.

25. Hanrahan, J.P. 1974. Crossbreeding studies involving Finnish Landrace and Galway sheep. Proc. Work. Symp. Breed Eval. and Cross. Exper., Zeist. pp. $431-444$.

26. Hanrahan, J.P. 1982. Results of crossbreeding experiments with sheep in Ireland. Proc. Wld. Cong. Sheep and Beef Cattle Breeding. Eds., Barton, R.A. and Smith, W.C., Dunmore Press, Palmerston North, New Zealand. Vol. 1: 125-132.

27. Hautakangas, E. 1984. Experiences of small sheep flocks in Finland. 35th Ann. Mtg of EAAP, The Hague, The Netherlands. 3 p.

28. Hofmeyr, J.H. 1982. Implications of experimental results of crossbreeding sheep in the Republic of South Africa. Proc. Wld. Cong. Sheep and Beef Cattle Breeding. Eds., Barton, R.A. and Smith, W.C., Dunmore Press, Palmerston North, New Zealand. Vol 1: 157-173.

29. Нонеnвoken, W.D. 1986. Costs and benefits of breed utilization strategies in sheep. Proc. 3rd Wld. Cong. Genetics Appl. Livest. Prod. 9: 509-522.

30. Hohenboken, W.D. \& Clarke, S.E. 1982. Genetic, environmental and interaction effects on lamb survival, cumulative lamb production and longevity of crossbred ewes. J. Anim. Sci. 53: 966-976.

31. Iniguez, L.C., Bradford, G.E. \& Mwai, Okeyo A. 1986. Lambing date and lamb production of springmated Rambouillet, Dorset and Finnsheep ewes and their F, crosses. J. Anim. Sci. 63: 715-728.

32. Kempster, A.J., Cutherbertson, A. \& Harrington, G. 1982. The relationship between conformation and the yield and distribution of lean meat in the carcasses of British pigs, cattle and sheep: a review. Meat Science 6: 37-53.

33. Kirton, A.H. \& Pickering, F.W. 1967. Factors associated with differences in carcass conformation in lamb. N.Z. J. Agric. Res. 10: 183-200.

34. LAND, R.B. 1970. The mating behaviour and semen characteristics of Finnish Landrace and Scottish Blackface rams throughout the year. Anim. Prod. 12: $551-560$.

35. Land, R.B., Russell. W.S. \& Donald, H.P. 1974. The litter size and fertility of Finnish Landrace and Tasmanian Merino sheep and their reciprocal crosses. Anim. Prod. 18: 265-271.

36. Lirette, A., Seoane, J.R., Minivielle, F. \& FroehLCH, D. 1984. Effects of breed and castration on conformation, classification, tissue distribution, composition and quality of lamb carcasses. J. Anim. Sci. 58: 1343-1357.

37. Magid, A.F., Swanson, V.B., Brinks, J.S., Dickerson, G.E. \& Sмiтh, G.M. 1981. Border Leicester and Finnsheep crosses. II. Productivity of $\mathrm{F}_{1}$ ewes. J. Anim. Sci. 52: 1262-1271.

38. Maijala, K. 1984. Review of experiences about the use of Finnsheep in improving fertility. Proc. 2nd Wld. Cong. Sheep and Beef Cattle Breeding. Eds., Hofmeyr, J.H. and Meyer, E.H.H., Pretoria, South Africa.: 519-531.

39. MaIJALA, K. 1988. History, recent development and uses of Finnsheep. J. Agr. Sci. Finl. 60: 449-454.

40. Maijala, K. \& Ósterberg, Siv 1977. Productivity of pure Finnsheep in Finland and abroad. Livest. Prod. Sci. 4: 355-377.

41. Meyer, H.H. \& French, R.L. 1979. Hogget liveweight-oestrus relationship among sheep breeds. Proc. N.Z. Soc. Anim. Prod. 39: 56-62.

42. Meyer, H.H. 1979. Ewe and teaser breed effects on reproductive behaviour and performance. Proc. N.Z. Soc. Anim. Prod. 39: 68-76.

43. Meyer, H.H., Clarke, J.N., Bigham, M.L. \& Carter, A.H. 1977. Reproductive performance, growth and wool production of exotic sheep and their crosses with the Romney. Proc. N.Z. Soc. Anim. Prod. 37: 220-229.

44. More O'Ferral, G.J. \& Timon, V.M. 1975. A comparison of sheep breeds and crosses for ewe productivity. Ir. J. Agric. Res. 14: 285-296.

45. Nitter, G. 1978. Breed utilisation for meat production in sheep. Anim. Breed. Abstr. 46: 131-143.

46. Nitter, G. 1987. Economic response to increasing genetic potential for reproductive performance. In: New Techniques in Sheep Production. Eds., I. Fayez, M. Marai and J.B. Owen. Butterworh \& Co., London.: 271-280.

47. Norman, L.M. \& Hohenboken, W.D. 1979. Genetic and environmental effects on internal parasites, foot soundness and attrition in crossbred ewes. J. Anim. Sci. 48: 1329-1337.

48. Oltenacu, E.A.B. \& Boylan, W.J. 1981a. Productivity of purebred and crossbred Finnsheep. I. Reproductive traits of ewes and lamb survival. J. Anim. Sci. 52: 989-997.

49. Oltenacu, E.A.B. \& Boylan, W.J. 1981b. Productivity of purebred and crossbred Finnsheep. II. Lamb weights and production indices of ewes. J. Anim. Sci. 52: 998-1006.

50. OWEn, J.B. 1976. The development of a prolific breed of sheep. 27. Ann. Meet. EAAP, Zürich, 4 p.

51. OWEN, J.B. 1987. Systems development of new techniques. In: New Techniques in Sheep Production. Eds. I. Fayez, M. Marai and J.B. Owen. Butterworth \& Co., London: 281-286.

52. QUIRKE, J.F. 1978a. Onset of puberty and oestrous activity in Galway, Finnish Landrace and Finn-cross ewe lambs during their first breeding season. Ir. J. Agric. Res. 17: 15-23.

53. QUIRKE, J.F. 1978b. Reproductive performance of Galway, Finnish Landrace and Finn-cross ewe lambs. Ir. J. Agric. Res. 17: 25-32.

54. Robinson, J.J. 1985. Nutritional requirements of the 
pregnant and lactating ewe. In: Genetics of Reproduction in Sheep. Eds. Land, R.B. and Robinson, D.W. Butterworths, London: 361-370.

55. Saoud, N.B. \& Hohenboken, W.D. 1984. Genetic, environmental and interaction effects on lifetime efficiency of crossbred ewes. J. Anim. Sci. 59: 594-606.

56. Schanbacker, B.D. \& Lunstra, D.D. 1976. Seasonal changes in sexual activity and serum levels of LH (luteinizing hormone) and testosterone in Finnish Landrace and Suffolk rams. J. Anim. Sci. 43: 644-650.

57. Sheehan, W. \& Quirke, J.F. 1984. The reproductive performance of Fingalway ewes mated three times in two years. Ir. J. Agric. Res. 23: 41-48.

58. Sмıтн, C., Kıng, J.W.B., Nicholson, D., Wolf, B.T. \& Bampton, P.B. 1979. Performance of crossbred sheep from a synthetic dam line. Anim. Prod. 29: 1-9.

59. Sorrenson, W.J. \& Scott, M.E. 1978. Economic evaluations of exotic sheep crosses in New Zealand. Proc. N.Z. Soc. Anim. Prod. 38: 71-78.

60. Steine, T. 1985. Genetic studies of reproduction in Norwegian sheep. In: Genetics of Reproduction in Sheep. Eds., Land, R.B. and Robinson, D.W., Butterworths, London: 47-54.

61. Terrill, C.E. 1982. Applications of experimental results of crossbreeding of sheep in the United States of America. Proc. Wld. Cong. Sheep Beef Cattle Breeding. Eds. Barton, R.A. and Smith, W.C., Dun- more Press, Palmerston North, New Zealand. Vol. 1: 115-123.

62. Tervit, H.R., Baker, R.L., Hoff-Jorgenson, R., Lintukangas, S., MacDiarmid, S.C. \& Rainio, V. 1986. Viability of frozen sheep embryos and semen imported from Europe. Proc. N.Z. Soc. Anim. Prod. 46: 245-250.

63. Treacher, T.T. 1985. The possibilities for improving the performance of ewes suckling three or more lambs in grazing systems. In: Genetics of Reproduction in Sheep. Eds., Land, R.B. and Robinson, D.W., Butterworths, London: 371-381.

64. Vesely, J.A. \& Swierstra, E.E. 1986. Reproductive parameters of crossbred ewe lambs sired by Romanov, Finnish Landrace, Dorset and Western Range rams. J. Anim. Sci. 62: 1555-1562.

65. Visscher, A.H. 1987. Development of a synthetic dam line in a reciprocal cross between Finnish Landrace and Ile de France in The Netherlands. Livest. Prod. Sci. 17: 77-87.

66. Young, L.D., Dickerson, G.E. \& Fogarty, N.M. 1985. Evaluation and utilization of Finn sheep. In: Genetics of Reproduction in Sheep. Eds. Land, R.B. and Robinson, D.W., Butterworths, London: 25 -38 .

67. Young, L.D., Dickerson, G.E., Ch'ang, T.S. \& Evans, R. 1986. Heterosis retention in sheep crossbreeding. Proc. 3rd World Cong. Genet. Appl. Livest. Prod. 9: 497-508. 